\title{
The Study of Artemisinin Content in Callus Artemisia annua L. Cultures Elicited with Endophytic Fungi Aspergillus sp.
}

\author{
Farida Yuliani ${ }^{12^{*}}$, Widyatmani Sih Dewi ${ }^{3}$, Ahmad Yunus ${ }^{3}$, Usman Siswanto ${ }^{4}$ \\ ${ }^{1}$ Doctoral Program of Agricultural Sciences, Sebelas Maret University, Solo, Indonesia \\ ${ }^{2}$ Department of Agrotechnology. Muria Kudus University, Kudus, Indonesia \\ ${ }^{3}$ Department of Agrotechnology Sebelas Maret University, Solo, Indonesia. \\ ${ }^{4}$ Department of Agrotechnology Tidar Magelang University, Magelang, Indonesia. \\ *email: farida.yuliani@umk.ac.id
}

Received October 29, 2018; Accepted November 30, 2018; Available online December 8, 2018

\begin{abstract}
Artemisinin, is a sesquiterpene lactone which is originally extracted from the medicinal plant Artemisia аппиа L. Artemisinin is a very effective antimalarial agent, however it is produced in very low amounts in plants. Chemical synthesis of artemisinin is complicated and not economically feasible. Researchers often use elicitation methods to increase artemisinin content in a laboratory scale with biotic or abiotic elicitor. This study examined the effect of elicitation using endophytic fungi Aspergillus $s p$ on artemisinin content of callus A. аппиа cultures. Observations were made on its growth, texture and color, chlorophyll content and dry weight. Fungi were isolated from the stem tissue of A. аппиа and callus were grown on Murashige and Skoog medium. After 3 weeks of incubation, callus treated with four different elicitors concentration $(0,2,4$, $6 \mathrm{mg} / \mathrm{mL}$ ). There were significant alterations on callus culture in terms of growth, texture, color and chlorophyll content after elicitation. The results clearly demonstrated that the endophytic fungal elicitor Aspergillus $s p$ could increase artemisinin content but did not affect the callus dry weight of A. аппиа. The treatment of $4 \mathrm{mg} / \mathrm{mL}$ elicitor produced the highest artemisinin content, that increased 7.6 times compared to the control, from $0.0036 \%$ to $0.0275 \%$.
\end{abstract}

Keywords : Artemisia annua, elisitor, Aspergillus sp., artemisinin

\section{INTRODUCTION}

Artemisinin, an endoperoxides sesquiterpene lactone originally extracted from the medicinal plant Artemisia annua L. (Compositae). It is an effective antimalarial agent, particularly for multi-drug resistant strains of malarial parasite and cerebral malaria, Plasmodium spp. Chemical synthesis of artemisinin is complicated and expensive. Until now the intact plant remains the only viable source of artemisinin (Aftab, 2014). Artemisinin is produced in very low amounts in A.аnпиа L. This becomes serious limitation factor for commercialization of drug base on artemisinin (Mehrjerdi, Bihamta \& Omidi, 2013). Plant scientists have focused their efforts on $A$. апnиa for a higher artemisinin crop yield.

In recent years plant cell/tissue culture techniques have emerged as a potential alternative for the mass production of secondary metabolites (Rai, Nehapandey \& Pandey-Rai, 2014). Treatment with elicitors is one of the most effective strategies for improving secondary metabolite production in plant tissue cultures, and has recently found commercial application (Zhao, Zhou and $\mathrm{Wu}$, 2010; Baskaran, Ncube \& Staden, 2012;
Sivanandhan, et al., 2012; Zaker et al., 2015). The type and structure of elicitors varies greatly. Abiotic elicitors: are substances of non-biological origin, predominantly inorganic salts, and physical factors acting as elicitors; they include Cuprum, Cadmium and Calcium ions, Methyl Jasmonate, Nitrite oxide and high $\mathrm{pH}$. Biotic elicitors, are elicitors with biological origin; they include polysaccharides derived from plant cell walls (pectin or cellulose), micro-organisms (chitin or glucans) and glycoproteins (Radman, Saez, Bucke \& Keshavarz, 2003).

Recent studies have shown that a wide range of elicitors can modify plant metabolism and result in elevated production of some secondary compounds, as well as accumulation of chemicals that would not usually be synthesized in the source plant (Cui, Wang \& Zhou, 2012).

Aftab, et al. (2010) studied the effect of various levels of Boron concentration (a micronutrient), on oxidative stress, antioxidants defense response and changes in artemisinin content in A.annua plants. The results showed that the boron treatments induced oxidative stress, and increasing levels 
of the boron concentration, result on increasing of the activity of antioxidant enzymes. A mild stress of boron can be utilized for enhanced artemisinin production. Sivanandhan, et al. (2012) report that the biotic elicitor, chitosan at $100 \mathrm{mg}^{-1}$ stimulated higher production of all Whitanolides (Indian Ginseng) when compared to abiotic elicitor aluminium chloride. Mehrjerdi et al. (2013) examined the exogenous effects of methyl jasmonate (MeJA) and 2-isopentenyladenine (2-iP) on the production of artemisinin and the main genes of its biosynthesis pathway in A. апnиa. Jasmonate acid and its methyl esters are known as molecules that play an important role in the regulation of gene reprogramming and biosynthesis of secondary metabolites in plant cells. The results showed that MeJA and 2-iP increase the content of plant artemisinin with few changes in the expression of the main genes of its biosynthesis pathway. There is no correlation between gene expression and artemisinin content.

A. апnua has been known to have endophytes, microorganisms that form symptomless infection within healthy plants tissues. Different Group of organisms such as fungi, bacteria, actinomycetes and mycoplasma are reported as endophytes of plants (Jalgaonwala, Mohite \& Mahajan, 2011). Various important characteristics are currently attributed to it, such as increase resistance to stressful conditions; alteration in physiological respons production of phytohormones, toxins, increment quality and quantity of medicinal substances, immunosuppressants, antitumor agents, and important compounds in biotechnological field such as enzymes (Backman and Sikora (2008); Yu, Zhang, \& Li (2010); Ja, et al. (2016). Some endophytic microbes have been used as biotic elicitors that can increase artemisinin production.

Wang, Zheng, Zhang \& Zou (2009) increased the production of artemisinin through elicitation using a combination of cerebroid derived from endophytic fungi and nitric oxide in $A$. annua hairy roots. The results showed that artemisinin production in 20 days old hairy roots increased 2.3-folds compared to controls.

Artemisinin biosynthesis has also increased in $A$. апnиa after treated with Piriformospora indica or arbuscular mycorrhizal fungi (Kapoor, Chaudhary \& Bhatnagar, 2007). Further, Li, et al. (2012) reported that endophytic inoculation of Pseudonocardia species in seeds could stimulate $A$. аппиа' artemisinin production. However there have been no reports of efforts to increase artemisinin levels using endophyte fungi Aspergillus $s p$. and the effect of elicitation using endophyte fungi on $A$. аппиа' callus cultures.

The purpose of this study was to increase the artemisinin content of A. апnиa plants through callus elicitation using endophytic fungal elicitor Aspergillus $s p$ and evaluate the effect of elicitation on callus cultures in terms of its growth, texture and color, and chlorophyll content.

\section{EXPERIMENTAL SECTION}

This study carried out in the tissue culture laboratory at the Faculty of Agriculture, Muria Kudus University.

\section{The A. annua plant Origin}

А.апnиа plants were taken from Research Center for Medicinal Plant and Traditional Drugs, Tawangmangu. Indonesia.

\section{Endophytic Aspergillus sp cultures}

Aspergillus $s p$ cultures used in this study were isolated from А.апnиa plant and was described based on its morphological characteristic and molecular experiment from the previous study.

\section{Callus Initiation}

Explants of cut leaf, planted in Murashige and Skoog (MS) medium enriched with plants growth regulator agents (1 ppm NAA and $1 \mathrm{ppm}$ BAP). Callus that grows in the sub-culture, were selected and chosen which has uniform growth.

\section{Preparation of elicitor}

The elicitation method was carried out and modified according to Astuti (2007). The fresh mycelium of Aspergillus sp, were grown on Potato Dextrose Agar medium at $28{ }^{\circ} \mathrm{C}$ for 5 days and inoculated into several $500 \mathrm{~mL}$ Erlenmeyer flasks containing $100 \mathrm{~mL}$ Potato Dextrose liquid medium. The cultivations were kept for 10 days at $28{ }^{\circ} \mathrm{C}$ and $150 \mathrm{rpm} /$ minutes on rotary shaker. The harvested mycelia were aseptically filtered with Whatman paper No.1 in Laminar Air Flow Cabinet and dried at 60 ${ }^{\circ} \mathrm{C}$. Dried mycelium crushed to form a powder and made it homogenate in sterile distilled water with a concentration of $0.0 ; 2.0 ; 4.0 ; 6.0$ 
$\mathrm{mg}$ dry weight $/ \mathrm{mL}$. The homogenates materials were sterilized at $121{ }^{\circ} \mathrm{C}$ and 15 psi for 20 minutes and ready to be used as an elicitor.

\section{Elicitation}

Elicitation was done by injecting 0.25 $\mathrm{mL}$ of elicitor on each-three weeks old of callus. In the control, callus was added with sterile distilled water with the same volume. Callus which had been elicited were incubated for 4 days at room temperature. Observations were made on the texture of callus and its color. After callus cultures were harvested, analysis were carried out on the total chlorophyll contents, the dry weight of callus and its artemisinin content.

\section{Analysis of total chlorophyll content}

Measurement was done before elicitation and after callus culture was harvested. It was carried out by extracting 0.1 $\mathrm{g}$ of sample in $20 \mathrm{~mL}$ Aceton. Extracts were filtered using Whatman paper No.1 and the absorbances were measured using UV Vis spectrophotometer (Setiari, Nurhayati \& Yuni, 2009; Banyo, Nio, Siahaan, \& Tangapo, 2013).

\section{Analysis of artemisinin content.}

Analysis of artemisinin content was carried out using High Performance Liquid Chromatograph (HPLC). The analysis was divided into two stages. Extraction and Derivation into Q260 (Pras, et al., 1991) with modification.

\section{Extraction.}

Callus of A. апnиa which has been dried and has constant weight, were crushed with mortar and weighed as much as $100 \mathrm{mg}$, added quartz sand and $2 \mathrm{~mL}$ toluene to create extracts. The extracts were further filtered, and the filtrate ready to be used.

\section{Derivation into Q260.}

For HPLC analysis, artemisinin was hydrolysed in alkaline solution. The product of hydrolysis, Q260, can be easily measured since it absorbs strongly at $260 \mathrm{~nm}$, while artemisinin itself only possesses a weak absorbance at the low end of the UV spectrum. The procedure was as follows , $500 \mu \mathrm{L}$ of toluene extract were evaporated to its dryness. The residue was dissolved again with $200 \mu \mathrm{L}$ of methanol. The $800 \mu \mathrm{L}$ of $\mathrm{NaOH}$ solution $(0.2 \%$ w/v) was added, then agitated with a vortex mixer. The mixture of solution further heated for 30 minutes in a $50{ }^{\circ} \mathrm{C}$ waterbath. After the solution cold, $200 \mu \mathrm{L}$ of methanol and $800 \mu \mathrm{L}$ of $0.2 \mathrm{M}$ acetic acid were added.

The mixture was further stirred until homogeneous and filtered with Whatman strain filter size of $0.45 \mu \mathrm{L}$. The $20 \mu \mathrm{L}$ of filtered solutions further injected into the HPLC instrument. The artemisinin was assayed as Q260 on a Vertex, Eurospher 100-5 C18, $150 \times 4,6 \mathrm{~mm}$ (AH 201). The mobile phase was $0.01 \mathrm{M}$ phosphate buffer: methanol $(55: 45 \%) \mathrm{pH} 7.0$ at a flow rate of 0,5 $\mathrm{mL} /$ minute : 7,0-7,0 Mpa. The artemisinin derivative was detected at $260 \mathrm{~nm}$. The rearrangement product. Q260, remained stable in solution for a period of at least four days at $4{ }^{\circ} \mathrm{C}$.

\section{Statistical test}

The experiment was carried out in a completely randomized design. The statistical test used to analyze the data is Least Significant Difference (LCD) at a 95\% confidence level with Minitab Programs.

\section{RESULTS AND DISCUSSION}

\section{Callus Texture}

The callus harvested have crumb and compact textures. Callus textures showed the development of callus. In the crumb callus, the cells still grow and differentiate with clear whites, yellowish green or green colors. But in compact callus, the cells were difficult to be separated and on maximum growth. In the compact and brown callus, the cells are old or dead. On the control and the treatment of 2 $\mathrm{mg} / \mathrm{mL}$ elicitor, callus has a yellowish green or whitish green color with crumb textures. In this treatment, elicitor did not affect callus textures but colors. The average callus texture is crumb. In the $4 \mathrm{mg} / \mathrm{mL}$ treatment, a compact callus texture or crumbs were produced. there were changes in texture and callus color after elicitation. In the treatment of $6 \mathrm{mg} / \mathrm{mL}$ most of the callus is brown. Many cells die. Only a small portion was still green and growing also has a compact texture (Table 1).

In elicitation treatment, discolorations are closely related to the presence of secondary metabolites in culture. According to Rai et al. (2014) high flavonoid content were found in fully grown callus and has no further differentiation. In callus that has stopped growing, phenol content is high. This is what may cause discoloration in the callus. Color changes in callus, indicate the occurrence of 
enzymatic reactions that lead to the synthesis of phenol compounds called browning (Phenolic synthesis induced by stress or disturbance in plant cells in the form of injury to the tissue and stress from the media (Widyawati, 2010). In this case, stress comes from the elicitor.

\section{Total chlorophyll content}

Measurement of chlorophyll contents were done after harvest. The average total chlorophyll contents were $2.73,2.53,2.16$, 1.68 in A. аппиа callus which were elicited with $0,2,4$ and $6 \mathrm{mg} / \mathrm{mL}$ elicitor. The total chlorophyll content decreases as the concentration of elicitor were enhanced. It resulted in changes textures and colors as well as dead cells of callus. It color became yellow or brown (Table 2). The high amount of chlorophyll $(2.73 \mathrm{mg} / \mathrm{g})$ were produced by the treatment of 0 and $2 \mathrm{mg} / \mathrm{mL}$ of elicitor. In the treatment of $6 \mathrm{mg} / \mathrm{mL}$ elicitor, the chlorophyll content decreased sharply, and the callus became brown (Figure 2).

Table 1. Textures and color of callus before and after elicitation

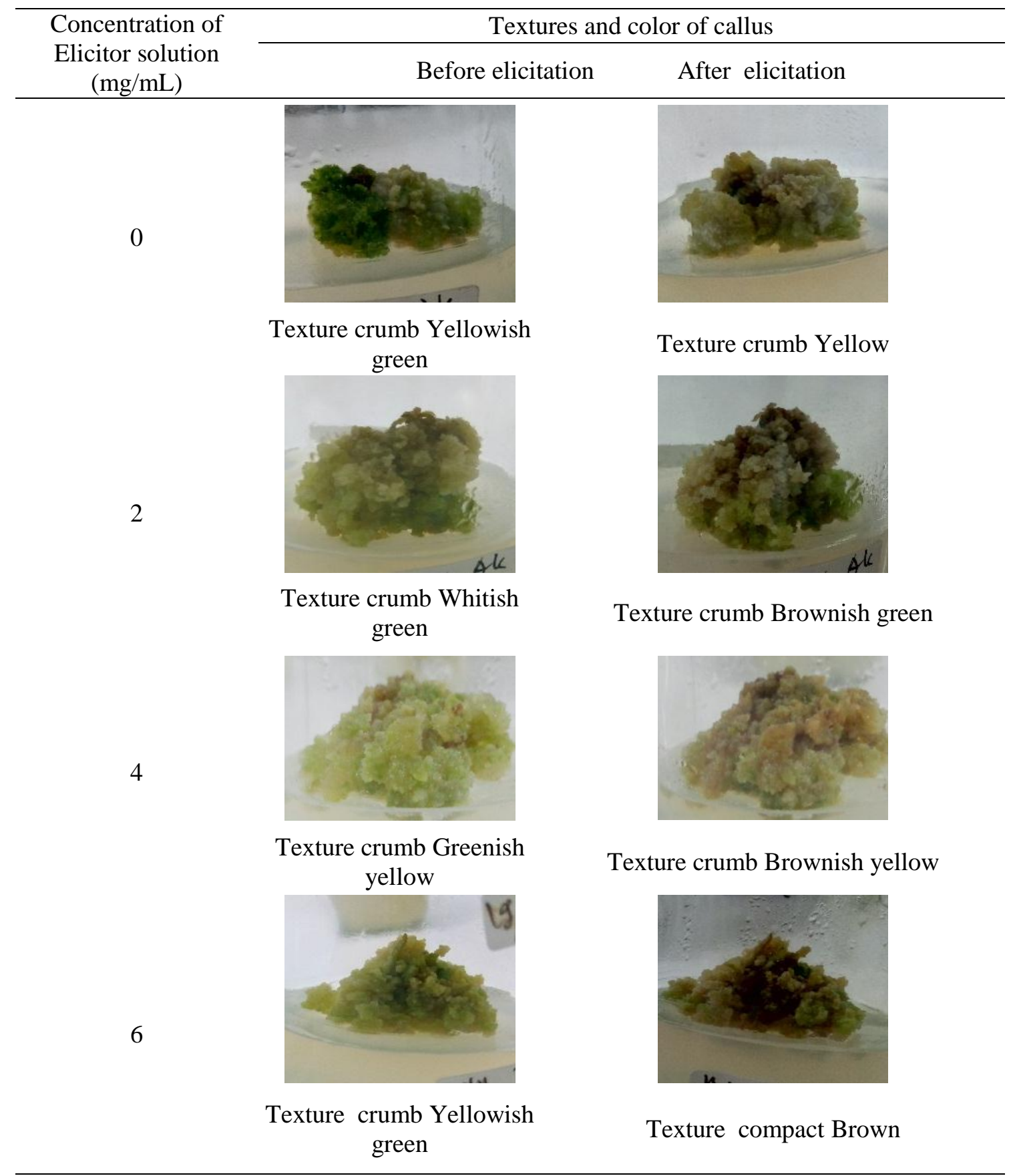




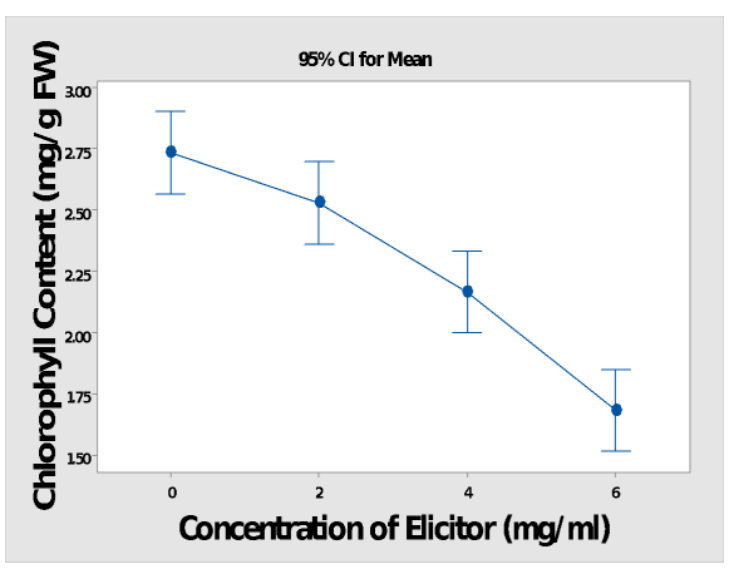

A.Chlorophyll

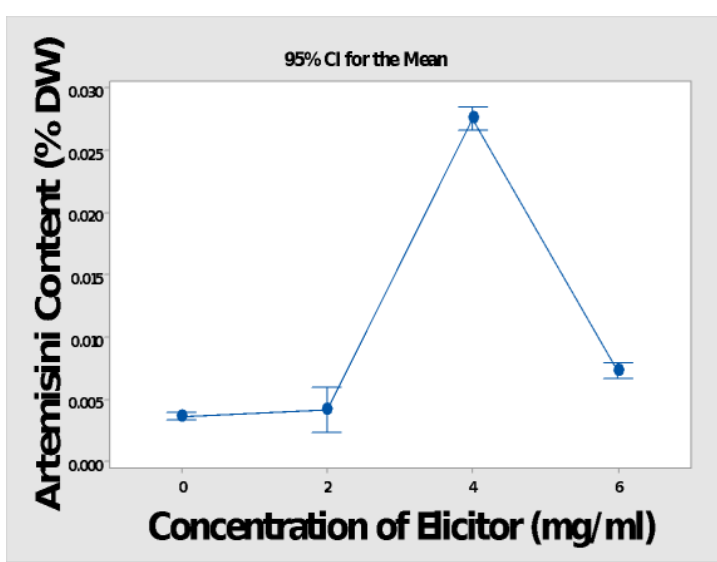

B.Artemisinin

Figure 1. Response of the total chlorophyll (A) and artemisinin (B) contents of A.annua callus against the elicitor concentration of Aspergillus sp.

This is related to the reduction of chlorophyll pigments in callus. When chlorophyll decreases, the rate of photosynthesis decreases, and respiration increases, thereby increasing the formation of secondary metabolites such as flavonoids (including artemisinin). This is in accordance with the results of research conducted by Rai $e t$ al. (2014) which showed that chlorophyll, carotenoids and flavonoids decreased if protein and phenol content increased and vice versa.

\section{Dry Weight (DW) of Callus and Artemisinin Content (\% DW)}

Elicitation treatments were carried out on the callus of aged 3 weeks, when the callus is in full growth. The treatment of Aspergillus $s p$ elicitor did not affect the dry weight of callus A. апnиa, but greatly affected its artemisinin content. The average dry weight of callus ranged from 666.7 to $745.9 \mathrm{mg}$. Callus dry weights were not affected by the treatment of elicitor. It was believed that elicitors act more in inducing secondary metabolites than the growth of callus (Astuti, 2007).

The unit for calculating artemisinin levels is percent per weight of dry matter. In this study the callus dry weight on control and elicited callus, did not change. This is very beneficial because artemisinin production did not decrease as a result of no changes in dry weight of callus.

The treatment of $4 \mathrm{mg} / \mathrm{mL}$ elicitor has significantly increased the artemisinin content until 7.6 times compared to the control, $0.0036 \%$ to $0.0275 \%$. While at a higher concentration of $6 \mathrm{mg} / \mathrm{mL}$ elicitor, the artemisinin content decreased to $0.0072 \%$.
(Table 2). The response pattern of the artemisinin content is described clearly in Figure 1B.

It was observed, on the treatment of 4 $\mathrm{mg} / \mathrm{mL}$ of elicitor, the callus stopped growing (where there was no further differentiation), the artemisinin content on callus $0.0275 \%$, was higher than other treatments.

Callus at the differentiation stage were observed in the control or in the treatment of 2 $\mathrm{mg} / \mathrm{mL}$ elicitor. At this stage there was a part of callus that is still growing. The content of artemisinin is $0.0036 \%$ and $0.00412 \%$ respectively, In the treatment of $6 \mathrm{mg} / \mathrm{mL}$ elicitor, a lot of dead cells were found after elicitation, thus artemisinin contents dropped to $0,072 \%$, was lower than the treatment of 4 $\mathrm{mg} / \mathrm{mL}$ elicitor.

The relationship between callus texture, chlorophyll content and artemisinin are explained below. At $4 \mathrm{mg} / \mathrm{mL}$ treatment, the callus texture turns into compact, the callus surface is brownish yellow, the lower callus is yellowish green, and the cell has not died but at the stage of maximum growth. Chlorophyll content decreases, from 2.73 in control to 2.16 (Table 2), caused low photosynthesis rate and increase respiration rate to get energy and precursors for the formation of secondary metabolites. Highest Artemisinin content was found $0.02752 \%$ (Table 2), according to Zulhilmi, Suwirmen \& Surya (2012) this was as an effort of plants for self-defense. This condition resulted in high artemisinin content in the treatment of $4 \mathrm{mg} / \mathrm{mL}$. The pattern of response of artemisinin content is shown clearly in Figure 1B. 
Table 2. Effect of Aspergillus sp. Elicitor Concentration on Total Chlorophyll, Dry Weight and Artemisinin Content of A.annua Callus in MS Media

\begin{tabular}{cccc}
\hline $\begin{array}{c}\text { Concentration of } \\
\text { Elicitor Aspergillus sp }\end{array}$ & $\begin{array}{c}\text { Total Chlorophyll } \\
\text { content } \\
(\mathrm{mg} / \mathrm{g} \text { Fresh Weight) }\end{array}$ & $\begin{array}{c}\text { Dry Weight of callus } \\
(\mathrm{mg})\end{array}$ & $\begin{array}{c}\text { Artemisinin content } \\
\text { of callus } \\
\text { (\% Dry Weight) }\end{array}$ \\
\hline $0 \mathrm{mg} / \mathrm{mL}$ solution & $2.73^{\mathrm{a}}$ & $745.9^{\mathrm{a}}$ & $0.00360^{\mathrm{c}}$ \\
$2 \mathrm{mg} / \mathrm{mL}$ solution & $2.53^{\mathrm{a}}$ & $682.1^{\mathrm{a}}$ & $0.00412^{\mathrm{c}}$ \\
$4 \mathrm{mg} / \mathrm{mL}$ solution & $2.16^{\mathrm{ab}}$ & $666.7^{\mathrm{a}}$ & $0.02752^{\mathrm{a}}$ \\
$6 \mathrm{mg} / \mathrm{mL}$ solution & $1.68^{\mathrm{bc}}$ & $671.5^{\mathrm{a}}$ & $0.00724^{\mathrm{b}}$ \\
\hline
\end{tabular}

Description: numbers within the same column which followed by the same letter shows no significant difference (5\% LSD).

In the treatment of $6 \mathrm{mg} / \mathrm{mL}$ elicitor, had produced of brown callus with compact texture, lowest chlorophyll content and decreased of the artemisinin content. Browning callus indicated many dead cells of callus. The results of microanalysis using electron microscopy were carried out by Wang et al. (2009), revealed that, cells that are dead after being elicited, there has been rapid accumulation of $\mathrm{Ca}$ ions and caused a high electron density in cortex cells. It was resulting in cytoplasmic condensation, shrinking cell size and nuclear fragmentation. Many dead cells of callus thus have resulted in decreasing of artemisinin content.

\section{CONCLUSION}

Elicitation made alterations on callus cultures in terms of growth, texture, color, chlorophyll and artemisinin contents. The amounts of total chlorophyll decreased as the concentration of elicitor were enhanced. Elicitation did not affect the dry weight of callus. The endophytic fungal elicitor Aspergillus sp could increase artemisinin content but did not affect the dry weight of $A$. апnиa callus. The treatment of 4 $\mathrm{mg} / \mathrm{ml}$ elicitor produced the highest artemisinin content, which has increased 7.6 times compared to the control, from $0.0036 \%$ to $0.0275 \%$.

\section{ACKNOWLEDGMENT}

Authors are thankful to Zed Nahdi, M.Sc. Dean, Dept. of Agrotechnology, Muria Kudus University, Kudus Indonesia, for providing laboratory facilities; Dr. Ir. Yuli Widyastuti (from B2P2TOOT, Tawangmangu, Karanganyar) for providing A. апnиa seedling.

\section{REFERENCES}

Aftab, T., Khan, M.M.A., Idrees, M., Naeem, M., Moinuddin, Hashmi, N. \& Varshney, L. (2010). Enhanching the Growth, photosynthetic capacity and artemisinin content in Artemisia аппиа L.by irradiated sodum Alginate. Radiation Physics and Chemistry. 80(7), 833-836

Aftab, A. (2014). Artemisia annua-Pharmacology and biotechnology. Berlin, Heidelberg : Springer. eBook: Document : English

Astuti, N.P. (2007). Reserpine content of Rauvolfia verticillata callus culture elicited by Pythium sp. Skripsi. FMIPA. Sebelas Maret University. Surakarta.

Backman P.A. \& Sikora R. A. (2008). "Endophytes: an emerging tool for biological control" Biological Control, 46 (1), 1-3.

Banyo, Y.E., Nio.S.A., Siahaan,P., \& Tangapo,A.M. (2013). The Chlorophyll Concentration In Rice Leaves Under Polyethylene-Glycol-Induced Water Deficit. Jurnal Ilmiah Sains, 13 (1), 1-9

Baskaran, P., Ncube, B. \& Staden, J.V. (2012). In vitro propagation and secondary product production by Merwilla plumbea (Lindl.) Speta. Plant Growth Regulation, 67, 235-245.

Cui, L., Wang, Z.Y. \& Zhou, X.H. (2012). Optimization of elicitors and precursors to enhance valtrate production in adventitious roots of Valeriana amurensis Smir. ex Kom. Plant Cell, Tissue Organ Culture. 108, 411-420.

Ja, M; Chen, L., Liang,H., Zheng,C.H., Rahman,K., Han,T. \& Qin,L.P. (2016). A Friendly Relationship between Endophytic Fungi and Medicinal Plants: 
A Systematic Review. Front Microbiol. 7, 906-912

Jalgaonwala, R.E., Mohite, B.Vi. \& Mahajan, R. T. (2011). A review: Natural products from plant associated endophytic fungi. Journal of Microbiology and Biotechnology. 1 (2), 21-32.

Kapoor R., Chaudhary V., \& Bhatnagar A.K. (2007). Effects of arbuscular mycorrhiza and phosphorus application on artemisinin concentration in Artemisia aпnиа L. Mycorrhiza 17, 581-587

Li J, Zhao G-Z., Varma A., Qin S., Xiong, Z., Huang, H-Y., Zhu,W-Y., Zhao,L-X., Xu,L-H., Hang, Zhang S., \& Li W-J. (2012). An Endophytic Pseudonocardia Species Induces the Production of Artemisinin in Artemisia annua. PLOS ONE, 7(12),1-9. www.plosone.org/

Mehrjerdi . M.Z., Bihamta, \& Omidi, M-R. (2013). Effect Of 2,4-D On Phenolics Production And Detection Of Invitro Culture-Induced Variation Through Inter-Simple Sequence Repeat And Rapd Analysis In Artemisia Annua L. International Journal of Pharma and Bio Sciences, 5(2),181 - 193

Pras, N., J. F. Visser, S. Batterman, H. J. Woerdenbag,T.M. Malingre And C.B. Lugt. (1991). Laboratory Selection Of Artemisia Annua L. For High Artemisini Yielding Types. Phytochemical Analysis, 2, 80-83.

Radman,R, Saez,T. Bucke, C. \& Keshavarz, T (2003). Review Elicitation of plants and microbial cell systems. Biotechnology Appied Biochemistry, 37, 91-102

Rai, K.K., Nehapandey \& Pandey-Rai S. (2014). Effect Of 2,4-D On Phenolics Production And Detection Of Invitro Culture-Induced Variation Through Inter-Simple Sequence Repeat And Rapd Analysis In Artemisia Annua L. International Journal of Pharma and Bio Sciences, 5 (2), 181 - 193

Setiari, N., Nurchayati, \& Juni,Y. (2009). Eksplorasi Kandungan Klorofil pada beberapa Sayuran Hijau sebagai Alternatif Bahan Dasar Food Supplement (Chlorophyll content exploration in green vegetables as food supplement base alternative ). BIOMA, 11 (1) : 6-10

Sivanandhan, G., Arun, M., Mayavan, S., Rajesh, M., Mariashibu, T.S., Manickavasagam, M., Selvaraj, N.,\& Ganapathi, A.(2012). Chitosan enhances withanolides production in adventitious root cultures of Withania somnifera (L.) Dunal. Industrial Crops and Product, 37, 124-129.

Widyawati.G. (2010). Pengaruh Variasi Konsentrasi Naa Dan Bap Terhadap Induksi Kalus Jarak Pagar (Jatropha Curcas L.) (The effect of Naa and Bap Concentration on Jatropha Curcas L. Callus Induction). TESIS . Program Pasca Sarjana Universitas Sebelas Maret Surakarta

Wang, J.W., Zeng,L.P.,Zhang, B. \& Zou,T. (2009). Stimulation Of Artemisinin Synthesis By Combined Cerebroroside And Nitric Oxide Elicitation In Artemisia annua Hairy Roots. Apply Microbiology and Biotechnology, 25 (2), 285-292.

Yu, L. H., Zhang, \& Li, L. (2010). "Recent developments and future prospects of antimicrobial metabolites produced by endophytes," Microbiological Research, 165 (6), 437-449.

Zaker, K.A., Sykora ,C., Gössnitzer, F., Abrishamchi, P., Asili ,J., Mousavi, S.H. \& Wawroschd. C.(2015). Effects of some elicitors on tanshinone production in adventitious root cultures of Perovskia abrotanoides . Industrial Crops and Products 67, 97-102

Zhao, J.L., Zhou, L.G. \& Wu, J.Y. (2010). Effects of biotic and abiotic elicitors on cell growth and tanshinone accumulation in Salvia miltiorrhiza cell culture. Applied. Microbiology and Biotechnology. 87, 137-144.

Zulhilmi, Suwirmen \& Surya N.W.(2012). The growth and qualitative test of secondary metabolite content of the callus culture of Spilanthes acmella Murr. with addition of PEG to induce drought stress. Jurnal Biologi Universitas Andalas 1(1), 1-8. 